\title{
EDUCATIONAL COMPONENT OF ALEXANDER DUKHNOVYCH'S PEDAGOGY
}

Стаття присвячена аналізу малодослідженої в історико-педагогічній літературі проблеми - внеску визначного педагога Олександра Духновича в теорію і практику національного виховання.

Розкрито основні концептуальні положення, на яких грунтується виховна концепція О. Духновича, їі зміст, методи та принципи виховання - народності, природовідповідності, культуровідповідності.

Виокремлено низку методів і засобів, які О. Духнович радив використовувати у національному вихованні: рідну мову як найважливіший засіб виховання патріотизму, історію як «вчительку життя», усну народну творчість, традичії й обряди, бесіду, приклад, переконання, заохочення, педагогічну вимогу, спілкування з духовним наставником, вивчення Біблії, виховання «страху Божого», віри, надії, любові, таїнства, молитву, участь у церковних службах та ін.

Сорормульовано кінцеву мету виховання виховання людини на славу Бога і на користь Батьківщині. Схарактеризовано О. Духновича як типового представника релігійного духу українства $і$ доведено, що домінантними напрямами в його концепції національного виховання $є$ морально-релігійне і патріотичне виховання.

Визначено низку християнських чеснот, на які повинні орієнтуватися вчителі та наставники у формуванні виховного ідеалу. На основі докладного студіювання різножанрової творчості О. Духновича визначено і схарактеризовано принципи і духовні цілі, що лежать в основі його духовної педагогіки принцип любові, христоцентричність, виконання заповідей Христа, грунтовне вивчення духовної та культурної спадщини рідного краю.

Наголошено на педагогічній цінності й актуальності виховних ідей і настанов О. Духновича на сучасному етапі національного відродження українського народу.

Стверджено, що сучасна українська школа повинна виховувати молодь в національнорелігійному дусі; домінантою має бути служіння Богові й Батьківщині, як учив ще в XIX $\mathrm{cm}$. духовнийнаставникОлександрДухнович. Ключові слова: виховання, виховна концепція О. Духновича, принципи виховання, патріотичне виховання, морально-релігійне виховання.
The article is devoted to the analysis of the little researched problem in the historical and pedagogical literature - the contribution of the prominent pedagogue Alexander Dukhnovych to the theory and practice of national education.

The basic conceptual provisions on which A. Dukhnovych's educational concept is based, its content, methods, and principles of education such as nationality, nature and cultural correspondence are revealed.

A number of methods and principles that A. Dukhnovych advised using in national education are distinguished: native language as the most important instrument of patriotic education, history as a "teacher of life", folklore, traditions and ceremonies, storytelling, example, persuasion, encouragement, pedagogical requirement, communion with spiritual master, Bible studying, education of the "fear of God", faith, hope, love, sacrament, prayer, participation in church services, etc.

The ultimate goal of education is formulated. It is interpreted as the education of man for the glory of God and for the benefit of the Motherland. A. Dukhnovych is characterized as a typical representative of the Ukrainian religious spirit. It is proved that the dominant directions in his concept of national education are moral, religious and patriotic education.

A number of Christian virtues, which teachers and mentors should use while the formation of the educational ideal, are identified. On the basis of the detailed study of various genre creativity of $A$. Dukhnovych the principles and spiritual goals that underlie in his spiritual pedagogy are determined and characterized. They are the principle of love, Christocentricity, the fulfillment of Christ's commandments, a thorough study of the spiritual and cultural heritage of the native land, etc.

The pedagogical value and relevance of A. Dukhnovych's educational ideas and principles are emphasized at the present stage of national revival of the Ukrainian people. It is stated that the modern Ukrainian school should educate young people in the national-religious spirit; serving of God and Motherland should be dominant, as spiritual advisor Alexander Duchnovych taught in the XIX century.

Key words: upbringing, $A$. Dukhnovych's educational concept, principles of education, patriotic education, moral and religious education.
Постановка проблеми у загальному вигляді. Історичний процес розвитку людства переконливо доводить, що більших успіхів у своєму розвитку і процвітанні завжди досягали ті народи, у яких виховання було кращим. Жодний державний устрій не дає людині ні доброти, ні любові, ні шляхетності. Ці якості з величезними труднощами і лише частково прищеплюються вихованням [21, с. 10].

Виховання у житті людей - первинне і головне, усе інше - його наслідки. «Там, де виховання відкладають до «кращих часів» і починають вирішувати інші, нагальніші і важливіші, як здається, про- блеми, ці кращі часи не настають ніколи, - слушно зауважує вчений І. Підласий. - Виховання - це саме життя, а життя «на потім» відкласти не можна» [21, с. 6]. Не буде перебільшуванням стверджувати, що наш стародавній народ вижив, зміцнів і зберіг свою автохтонність завдяки вихованню, завдяки тому, що вистражданий попередніми поколіннями досвід наслідувався, використовувався і примножувався прийдешніми.

Ідеологія незалежної держави, ідеологія державотворення $€$ сьогодні основою виховання як соціального явища. Сучасні українські науковці 
розглядають виховання 3 різних сторін: як аспект цілеспрямованого фрормування особистості (С. Гончаренко, І. Зязюн, М. Фіцула, М. Ярмаченко та ін.), як елемент управління розвитком (І. Бех, Т. Ільїна, О. Киричук та ін.), як складову частину культури (В. Бондар, Г. Васянович, М. Євтух, Л. Хомич та ін.), як виховання на традиціях українського народу (О. Вишневський, А. Вихрущ, Т. Завгородня, В. Кемінь, І. Підласий, Ю. Руденко, О. Сухомлинська, Ю. Тхоржевський та ін.).

Державотворчий процес виявив суттєві недоліки в галузі теорії та методики виховання. На наш погляд, вони зумовлені передусім тим, що у попередній період будівництва СРСР як закритого, денаціоналізованого суспільства виховання ґрунтувалося на принципах псевдоколективізму і псевдоінтернаціоналізму, а любов до України та рідного краю з високих партійних трибун оголошувалася найтяжчим злочином проти «соціалістичної Вітчизни» та замахом на «віковічну дружбу народів-братів» [24, с. 17, 23, 25, 28, 60-64]. Головною метою етнополітики Москви було перетворення українського народу в народ-безбатченко, народ без історії, мови та традиції, щоб легше було його асимілювати - злити з народом російським у єдину «радянську націю» 3 російською мовою та культурою. І все це розходилося з духом української, насамперед народної педагогіки, здобутки якої відображені у працях видатних вчених-педагогів.

Вагомий внесок у створення національної системи виховання зробив закарпатський мислитель Олександр Духнович (1803-1865) - один із перших професійних вчених-педагогів в Україні. Його спадщина і сьогодні має значну історико-педагогічну і науково-пізнавальну вартість.

Аналіз останніх досліджень і публікацій. Постать Олександра Духновича привертала увагу багатьох українських, словацьких і чеських дослідників - О. Машталера [17], М. Ричалки [23], О. Рудловчак [25], В. Туряниці [28; 29], О. Сухомлинської [27], Д. Федака [31], О. Фізеші [32] та ін. Автори одностайно наголошують на тому, що творча спадщина О. Духновича пронизана ідеями народності, демократизму та гуманізму.

На жаль, у радянські часи, в умовах заборони діяльності Української греко-католицької церкви як «антинародної сили» науковцям не дозволялося неупереджено аналізувати О. Духновича як теолога і виразника релігійного духу українства, і це сприяло забуттю великої частини його спадщини, а отже, спотворенню та збідненню наших знань про мислителя. Марксистсько-ленінська фрілософрія створила та протягом довгих років підтримувала міф про користь атеїстичного і безумовне зло релігійного виховання, який міцно вкоренився у свідомості багатьох педагогів і відображений, зокрема, у працях духновичезнавців О. Машталера, М. Ричалки, О. Рудловчак та ін.
Означена проблема частково висвітлена у книгах В. Туряниці, однак вузлові проблеми виховної системи вченого описано фррагментарно у найбільш загальних рисах. Важко погодитися з тезою автора, що в основу морального виховання О. Духнович ставить (крім загальнолюдських цінностей і норм) також почуття національної гідності та патріотизм [29, с. 33]. Отже, розроблені О. Духновичем педагогічний зміст і завдання морального і патріотичного виховання чітко не розмежовуються.

Окремі аспекти досліджуваної проблеми з історії педагогіки на Закарпатті висвітлено в праці О. Фізеші [32]. Дослідниця розкрила значення педагогічних ідей О. Духновича, висвітлила його внесок у розвиток шкільництва і підручникотворення, однак з огляду на тематичне спрямування та на широкі межі дослідження основи виховної концепції закарпатського мислителя охарактеризовано поверхово.

Виділення невирішених раніше частин загальної проблеми. Важливий виховний сегмент доробку О. Духновича, передусім зміст і принципи його духовної педагогіки, як і назагал історія розвитку виховних ідей на Закарпатті, не був комплексно висвітлений та осмислений в історико-педагогічній літературі. На наш погляд, дається взнаки недооцінювання окремими авторами провідної ролі виховання в педагогічному процесі. Воно виявляється, зокрема, в тому, що в педагогічній науці та практичній діяльності методика навчання і методика виховання нерідко дублюються.

Мета статті полягає у розкритті змісту, провідних напрямів і принципів виховної концепції О. Духновича та з'ясуванні його внеску в теорію і практику національного виховання.

Виклад основного матеріалу. Слово «виховання» $€$ похідним від слова chovati - вирощувати. В українській народній педагогіці воно спочатку вживалося у значенні «оберігати (ховати) дитя від небезпеки - хвороби, каліцтва, смерті, шкідливого впливу». Згодом це слово набуло значення «вирощувати дітей, навчати правил доброї поведінки» [13, с. 38]. 3 поняттям «виховувати» у народній педагогіці (цей термін у науковий обіг ввели О. Духнович і К. Ушинський) тісно пов'язане поняття «навчати».

Навчання, що є важливою педагогічною категорією, - це процес, за допомогою якого передається суспільно-історичний досвід: знання, вміння, навички. Інакше кажучи, навчання $€$ найважливішою складовою частиною виховання, що є поняттям значно ширшим, об'ємнішим і складнішим та охоплює розвиток особистості, її навчання й освіту [15, с. 7]. На думку К. Ушинського, «виховання бере людину всю, якою вона є, з усіма її народними та поодинокими особливостями, - її тіло, душу й розум» [30, с. 51]. Тому ототожнення понять 
навчання і виховання, якщо вважати, що навчання може поєднати і те, і те, на думку С. Карпенчука [15, с. 8], є великою помилкою, якої нерідко припускалися у процесі розвитку педагогічної науки та практики, особливо прихильники т. зв. «виховуючого навчання». «Педагогіка - це наука про виховання людини» [18, с. 8], - виразно стверджує вчений В. Мосіяшенко. Такої ж думки дотримувався ще у XIX ст. О. Духнович [7, с. 7].

У педагогічній спадщині О. Духновича обґрунтовано зміст виховання - це комплекс ідей, думок, чинників, основних напрямів виховного впливу. Передусім розглянемо принципи виховання, які у творчому доробку закарпатського вченого посідають важливе місце. Сучасні дослідники подають таку дефініцію: «Принципи виховання - керівні положення, що відображають загальні закономірності процесу виховання і визначають вимоги до змісту, організації та методів виховного процесу» [1, с. 400]. Українські вчені виділяють такі найважливіші принципи виховання [33, с. 501]:

Природовідповідність виховання - врахування багатогранної та цілісної природи людини, вікових та індивідуальних особливостей вихованців, їхніх соціально-психологічних, національних і релігійних особливостей.

Народність - єдність національного і загальнолюдського у вихованні. Національна спрямованість виховання, фрормування національної свідомості та самосвідомості, любові до рідної землі та свого народу: оволодіння рідною мовою, використання всіх її багатств і засобів у мовній практиці.

Культуровідповідність виховання - органічний зв'язок з історією народу, його мовою, з народним мистецтвом, ремеслами і промислами, забезпечення духовної єдності, наступності та спадкоємності поколінь.

Ще у XIX ст. О. Духнович на основі норм християнської моралі у своїх творах обґрунтував систему базових ідей виховання духовно зрілої та моральної особистості. Вся система педагогічних ідей мислителя була пройнята принципами народності, спорідненості (природовідповідності), гуманності та культуровідповідності. Означені принципи мають позачасове, загальнолюдське значення і можуть бути застосовані і за сучасних умов для розробки мети, завдань, а також систем фрорм і методів виховання моральної особистості.

На особливу дослідницьку увагу заслуговують принципи природовідповідності та народності виховання у розумінні О. Духновича, оскільки, на нашу думку, вони становлять теоретико-методологічну основу його виховної концепції.

Як і Я. Коменський і Г. Сковорода, О. Духнович ставив вимогу у процесі виховання «в усьому слідувати природі», отже, розвивати природні дані дитини. На відміну від Ж. Руссо, котрий ідеалізував природу дитини, і Дж. Локка, у теорії якого всі діти від природи рівні, О. Духнович вважав, що «кожна людина за природними нахилами або темпераментом на якусь річ схильність має» [7, с. 23]. Виховання в його розумінні важливе, оскільки завдяки йому людина стає людиною, але не всесильне. Воно «не змінює природної обдарованості <..> а тільки виявляє і розвиває її» [7, с. 7]. Педагогічна вимога природовідповідності виховання, отже, ґрунтувалася на глибокому знанні індивідуальних якостей дитини, її «природного нахилу». Дитина - представник певного етносу, 3 його характерними особливостями. Звідси - природовідповідність в О. Духновича не лише «єство, натура, наука і звичай» [7, с. 3], але й громадянська доброчесність, обов'язки людини перед своїм народом і батьківщиною, її моральне обличчя.

Аналіз вчення О. Духновича показує, що його система виховання й освіти повністю відповідає потребам народу, тобто проникнута ідеєю народності. Народність - один із головних соціальних мотивів його поезії, рукописних творів, письменницької та педагогічної діяльності. Вчений поклав думку про те, що закарпатські українці, як і інші народи, повинні мати школу 3 рідною мовою навчання, побудовану відповідно до потреб, менталітету і національних традицій народу. Лише така школа, на його думку, здатна піднести національну свідомість народу і врятувати його від денаціоналізації.

У 1850 р. О. Духнович сорормулював засади організації освіти на Закарпатті, визначив її систему для всіх вікових категорій населення незалежно від соціального стану і віросповідання, підкреслюючи, що кожна дитина має «право на життя і на хліб» [3, с. 26] і повинна мати право і на освіту.

Важливо зазначити, що у трактуванні О. Духновича народність виховання є категорією не тільки соціальною, а й моральною: в ньому поєднуються особисті прагнення 3 інтересами карпатоукраїнського народу, особистий добробут із добром рідного краю. Відтак виховання набуває особливого морального сенсу, оскільки сприяє розвитку духовного світу людини, готує її до життя, до служіння Батьківщині, народу.

У своїх історичних дослідженнях і публіцистичних виступах О. Духнович протестував проти спроб принижувати гідність українського населення, доводив, що українське населення $є$ автохтонним для Закарпаття, а Карпатський регіон - не периферія, а центр Європи. 3 гордістю він пише: «русини своїм обдаруванням переважають багато інших народів, а їх оголошувана бездарність $€$ наклепом ворогів» [8, с. 59]. Як бачимо, О. Духнович відстоює патріотичну думку про те, що українці (за тодішньою термінологією «русини») - народ давній і обдарований, і коли йому будуть забезпечені можливості здобути освіту, його чекає велике майбутнє. Тому він прагне всіма засобами та 
силами пробудити в народних масах українського Закарпаття потяг до освіти, до закладання шкіл, щоб таким чином швидше пробудити в народі національну свідомість і гордість.

Він водночас доводив, що українське населення Закарпаття - це не «угроруси», а кровні брати тих слов'ян, що живуть за Карпатами. Цим самим О. Духнович будив почуття патріотизму, посилюючи народні змагання до возз'єднання 3 Галичиною, Буковиною, іншими українськими землями. Він закликав любити свій народ, вірно йому служити, віддавати всі сили для його добра, ніколи не цуратися свого, рідного.

«Кто свое не терпит,

А за чужим прагнет,

Тот свое погубить,

Чужого не найдет», - писав О. Духнович [3, c. 217].

О. Духнович вважав, що почуття національного $€$ вродженим і властиве кожній людині. Найкраще у світі $є$ те, що своє, що рідне, а тому в основі виховання повинен бути дух рідного народу. Любов до народу, до своєї національності, яку, за його словами, не можна затаїти, як не можна затаїти свою кров, треба виховувати змалку у природному для учня етнічному середовищі з урахуванням національного менталітету. Він закликав кожного інтелігента, кожного співвітчизника: «Люби родтвой, не про то что он славный, но для того что он твой» [3, с. 86], «Отечеству своєму вьрный буди, Отечество бо есть тебъ Колибель... Кто Отечества свое не почитает той сирота есть, без Отца, без Матери - но и без всего» [3, с. 87]. Закликав учителів і батьків виховувати у дітей молоді любов до рідної Вітчизни та свого народу. «Оучителю, - писав О. Духнович, - також де на совђсти да будетъ, чтобы въ дђтяхъ народолюбіє возбудилъ и въ сердца их заскђпилъ любов къ своєй народности; ибо человькъ безъ народности подобень есть скитающемуся волку которому всякій льсъ отечествомъ єсть...» [7, с. 59]. А малим дітям - «соколятам» давав батьківське напучення: жити треба для своєї вітчизни, остерігатися чужини, бо «чуже в нас не устроїться» [22, с. 20].

Якщо ж із дитинства педагоги та батьки не привчатимуть дітей любити свій народ, не прищеплять їм любові до своєї Батьківщини, - ніби заглядаючи в майбутнє, застерігає славетний закарпатський мислитель, - то 3 них виростуть «равнодушные», «индеферентисты» «есть найбольшое зло в человђчествђ, ибо такій чоловђк ни сюда, ни туда, бывает самолюбец <..> опасный, стыдяся народом своим, стыдится самого себя» [7, с. 60]. «Індеферентистів», як він називає космополітів, не без підстав порівнює з вовками або «волоцюгами» [3, с. 152]. Як і Т. Шевченко, О. Духнович гостро засуджував зрадництво, запроданство, космополітизм, ренегатство, висміював схи- ляння, низькопоклонство перед іноземщиною, байдужість до життя свого народу, зневагу до рідної мови та культури. Наведені роздуми видатного закарпатського педагога не втратили педагогічної вартості на сучасному етапі відродження української освіти.

Своєрідними вершинами поетичної майстерності О. Духновича є громадсько-патріотична лірика: програмний вірш «Вручаніе», який став народним гімном русинів-українців Закарпаття та східної Словаччини, «Любов милой, и Отечества» (1852), «Поздравленіе Русиновъ на Новый годъ 1852» (1852), «Гласъ Радости...», «Посльдная моя пьснь» (1862), «Сирота в заточеніи», в яких він висловив своє громадянське, патріотичне та поетичне кредо. Аналіз тематичної спрямованості вірша «Я Русинъ» («Вручаніе») у контексті тогочасної доби засвідчує, що в ньому йдеться про опозицію «русин (українець) - угорець»; він спрямований проти таких русинів, котрі, піддавшись асиміляційному тиску, називали себе «мадярами».

Привертає увагу той сракт, що у 30-ті рр. минулого століття політикани готові були «розпинати» О. Духновича за його українство. Вочевидь, йдеться про вірш «Бо свои то за горами...» [14, с. 15-16], у якому він закликав до єдності всіх українців.

О. Духнович цілеспрямовано орієнтує батьків і вчителів виховувати дітей у дусі «народолюбія» [7, с. 38]; в дусі «руського», тобто українського патріотизму. Радить звертатися до історії свого народу, до життя «древних славних греков и римлян» [7, с. 38], а не до історії Австрії чи Угорщини, які вважав «чужиною».

Одним із засобів втілення в життя ідей народності виховання, стрижнем і ключовим чинником виховання патріотизму О. Духнович, як і інші українські педагоги й освітні діячі другої пол. XIX - поч. XX ст. [2; 19; 30], визнавав рідну мову, вивчення широкої сукупності відомостей (історичних, географрічних, етнополітичних) про рідну землю. Важливого значення надавав історії, фольклору та народній педагогіці як праосновам формування патріота. Завдяки О. Духновичу поняття «патріотичне виховання» збагатилося такими етнічно спрямованими складниками, як любов до рідної землі, рідних традицій, рідного слова, рідної природи.

У новаторському підручнику з географії та історії «Краткій землеписъ для молодыхъ Русиновъ» О. Духнович підкреслює, що кожний народ залишається народом, доки зберігається його мова, звичаї, культура, традиції, релігія, любов до батьківщини [6, с. 217]. Подібні думки про значення материнської мови в духовному житті народу, освіті та педагогіці висловлював також І. Огієнко. Рідну мову він визначає як душу народу та як його живе серце: «Гине чи занепадає мова - гине і занепадає народ» [19, с. 219]. 
Особливо слід наголосити на тому, що більшість художніх творів, публіцистичних і художніх праць О. Духнович написав українською мовою, радив очищати їі від слів чужих (полонізмів, мадяризмів, германізмів). У його творах часто зустрічаються загальноукраїнські лексичні елементи типу «батько», «бачити», «волоцюга», «дідько», «листопад», «мова», «прапор», «хата», «цвітень» та ін., яких на Закарпатті тоді ще не було. До того ж, треба брати до уваги той фракт, що книги на Закарпатті тоді видавалися церковнослов'янською або латинською мовами, малозрозумілими для народу. І те, що О. Духнович відійшов від цих традицій, писав рідною мовою, було кроком уперед на шляху боротьби за демократизацію мови, освіти, проти денаціоналізації українського населення, стало значним вкладом у розвиток української культури й освіти. Одним із перших О. Духнович своїми народномовними букварами та іншими працями педагогічного спрямування почав закладати фрундамент національної освіти в Україні, що відіграла важливу роль як заслін національної асиміляції.

У контексті нашого дослідження важливо також зазначити, що О. Духнович виступив проти вживання двох мов у ранньому віці та наполегливо радив, щоб навчання у початковій школі здійснювалося рідною мовою. Тільки на основі материнської мови у вихованців найбільш ефективно фрормується національна психологія, характер, світогляд, свідомість, самосвідомість та інші компоненти духовності народу. Отже, О. Духнович українську (русинську) мову розглядав не лише як етнодиференціюючу, але й як етноформуючу ознаку.

У «Народній педагогії» та інших працях О. Духнович торкається проблем методів і засобів національного виховання - способів досягнення прогнозованих цілей і завдань. Кожен предмет, що вивчається у школі, повинен, наголошує О. Духнович, нести зерно патріотичного виховання. Крім мови, важливого значення надавав історії як «вчительціжиття», яка забезпечує духовну єдність поколінь, праоснові фрормування патріота з високим рівнем національної свідомості та гордості, з почуттям любові до рідної землі та свого народу. Вся його творчість пройнята історизмом, про що свідчить студіювання поезії, прози, педагогічних та історичних праць, епістолярної спадщини просвітника.

Важливу роль педагог відводить фрольклору взагалі та народній пісні зокрема, бо вона «збуджує дух народолюбія» [7, с. 59]. О. Духнович у розробленому ним навчальному плані для початкових класів вимагає впровадити народний спів як окрему навчальну дисципліну, що розвиває в учнів як естетичні смаки, так і почуття патріотизму. Радив також використовувати у вихованні такі методи, як бесіда, розповідь, приклад, переконання, заохочення, педагогічна вимога.
Ключовою категорією педагогічної науки, вихідним пунктом теорії та практики виховання $є$ проблематика мети. Мета виховання визначає основні напрями виховного процесу в усіх його складових частинах, а також зумовлює зміст, принципи, форми та методи виховання.

Поборник національного відродження, О. Духнович метою виховання вважав виховання на славу Бога і на користь Батьківщини: «Первая обязанность человька єсть ко Богу, другая же - къ своєму народу» [7, с. 59-60]. І далі: «вірним будь, Вітчизна бо є твоя колиска, вона буде і домовиною твоєю. Хто вітчизну свою не поважає, той сирота, без батька, без матері, без усього» [3, с. 87]. Як бачимо, мета національного виховання в розумінні О. Духновича має суспільний характер, відзначається універсальністю і чіткою конкретизованістю.

Цю важливу постанову закарпатського мислителя розвинув і наповнив державотворчим та ідеологічним змістом видатний педагог Григорій Ващенко, котрий фрормулює такий імператив: «Коли найбільша чеснота українця - безмежна відданість Богові їі Батьківщині, то найбільша ганьба для нього - зрада вірі й Україні... Єдине гасло, під яким має проводитися виховання української молоді є: Служба Богові й Батьківщині» [2, с. $174,183,185]$.

Вбачаючи у християнстві виховний потенціал, великого значення О. Духнович надавав духовному збагаченню особистості засобами релігійного вчення і виховання, ратував за поширенням культури, гуманістичне і духовно-релігійне виховання дітей закарпатців їхньою рідною мовою. Вивчення життєпису просвітника засвідчує, що основним своїм життєвим кредо він вважав поширення в народі науки Христової, виховання молоді в дусі християнської моралі - любові до Бога й до ближнього, смиренства, правдивості, пошани до старших і батьків.

Виховним ідеалом О. Духновича-священнослужителя і теолога був християнський ідеал, накреслений у Святому Письмі і творах славетних мислителів; християнська мораль була покладена в основу його виховної системи. У релігієзнавчій літературі релігійна мораль тлумачиться як сукупність освячених будь-якою релігією правил, норм, приписів та оцінок, що визначають обов'язки людей перед Богом, перед іншими людьми, перед суспільством [26, с. 88].

Визначення змісту й особливостей системи морально-релігійного виховання у трактуванні О. Духновича, як і інших культурно-освітніх діячів минулого, є складним дослідницьким завданням. Осягнути непідвладний «обмеженому людському розуму» релігійний феномен, що охоплює світ не лише «видимий», а й «невидимий», як стверджують богослови, можна лише за допомогою інтуїції $[16$, c. 99]. 
Поряд 3 І. Вишенським, митрополитом Іларіоном, Г. Сковородою, Т. Шевченком, П. Юркевичем та ін. Олександр Духнович був типовим виразником релігійного духу українства. Всю навчальновиховну роботу в школі він наполегливо радив учителям підпорядковувати завданням виховання в дітей доброчесності та богобоязності, вважаючи це обов'язком сумління вчителів: «да будетъ Оучитель зерцаломъ своихъ оучениковъ...» [7, с. 24]. По-сучасному звучить також адресована батькам у середині XIX ст. порада мислителя: «Дай сыну твоєму здоровый разумъ, дай ему добрый нравъ, дай ему науку, способность, трудолюбіе, доброесердце, любов къ Богу и ближнему, заскепи в душу его страхъ Господень, дай ему добрую волю, и уже далъ еси ему богатство...» [7, с. 4-5]. У цій настанові в концентрованій формі сорормульовано концептуальні засади виховання та виокремлено основні його напрями: інтелектуальне, трудове, релігійне («дай ему... любов къ Богу и ближнему, заскепи в душу его страхъ Господень»), моральне («дай ему... добрый нравъ..., доброе сердце») виховання.

Християнську виховну спрямованість має «Книжиця читалная для начинающихъ» (Будин, 1847 р.) - перший закарпатоукраїнський буквар, написаний народною мовою; видатне явище в українській педагогіці. За цим букварем діти навчалися в початкових школах краю у 50-60ті pp. XIX ст. і пізніше, на початку XX ст. За своїм змістом буквар спрямований на доброчесне виховання юнаків і дівчат, на утвердження кращих рис характеру - простоти, скромності, ввічливості, честі, чесності, людської гідності, побожності. Його школярик прагне над усе «Богу послужити». Весь день учня повинен супроводжуватися молитвами, які не повинні бути показними й багатослівними. У «Книжиці...» наголошується на тому, що дитина вчитися «каждому честь давати» - вчителям, батькам, людям старшого віку [10, с. 22, 32].

У «Книжиці...» наведені норми поведінки при вході й виході з дому, школи, церкви, під час ігор та інших занять. Засвоюючи викладені в букварі поради і приписи, дитина засвоювала не лише грамоту, але й культуру поведінки та спілкування [10, с. 39-40].

Важливу роль у підготовці людини до життя О. Духнович відводив, як бачимо, їі моральній вихованості. Головними методами й засобами релігійно-морального виховання дітей і молоді він, так само як його однодумець К. Ушинський, вважав переконання, заохочення і покарання, власний приклад учителя, батьків і старших, рідну мову, усну народну творчість, традиції й обряди, а також спілкування 3 духовним наставником, вивчення Біблії та молитовників, виховання «страху Божого», віри, надії, любові; таїнства, молитву, участь у церковних службах тощо.
Погляди на виховання відображено і в укладених О. Духновичем 1862 р. «Правилах для воспитанников» товариства св. Іоанна Хрестителя [20], головою і духовним наставником якого був він сам. О. Духнович виховував малозабезпечених учнів у дусі християнського благочестя, народних цінностей, національних традицій, звичаїв, рідної культури. Педагог учив юнаків і дівчат, як їм жити, у що вірити, до чого прямувати, пробуджував у вихованців віру і надію, заспокоював розум, через що допомагав їм перебороти почуття страху і тривоги, самотності й невпевненості у своїх силах; своїм прикладом робив їх чуйними до потреб інших людей і зміцнював їх в альтруїзмі (безкорисливості). Як зауважує відома дослідниця О. Сухомлинська, цим духом християнської любові та благочестя пронизана вся його творча діяльність [27, с. 269, 274].

Можемо визначити загальні риси педагогічного спрямування творів О. Духновича. «Начало премудрое - страх Божий» [9, с. 10] - лейтмотив усіх його педагогічних настанов. Головний обов'язок дітей - виконувати повинності щирого християнина [11]: ходити до церкви й дотримуватися заповідей Божих у повсякденному житті; поважати й шанувати своїх батьків, учителів; доброзичливо ставитися до своїх товаришів, не допускати виникнення сварок і бійок; правильно поводитися всюди: вдома, у церкві, на вулиці, в гостях, за обідом (під час трапези), у школі та під час ігор. Батькам і вчителям слід виховувати дітей передусім похвалою, позитивним впливом, гарним прикладом, а також позбавляти їх поганого товариства; вчитель повинен бути людиною високих моральних засад, сприймати справу виховання надзвичайно відповідально, адже йому доведеться звітувати за це перед Богом; добре вихована дитина буде надійною опорою батьків на старість. Як бачимо, О. Духнович розумів процес духовно-морального виховання як складний процес утвердження в дитині добра.

У роздумах мислителя, які спираються на догмати християнства, людина постає об'єктом Божественної любові з правом на індивідуальне самовираження у поєднанні 3 високою відповідальністю перед суспільством і батьківщиною. Метою релігійного виховання, у розумінні О. Духновича, є розвиток духовності дитини, введення їі у світ вищих абсолютів і смислів людського буття, виховання особистості - носія християнських рис: милосердя, щирості, співчуття, любові.

Аналіз художнього, публіцистичного і наукового доробку О. Духновича дає змогу визначити низку християнських чеснот, на які повинні орієнтуватися вчителі та наставники у формуванні виховного ідеалу. До них належать здатність співпереживати, симпатія, справедливість, віра, вірність, почуття товариськості, здатність вибачати, ввіч- 
ливість, великодушність, готовність допомагати, совість, чесність, щирість, оптимізм, доброта, любов, слухняність, терпимість, миролюбність, наполегливість, готовність покладатися на Бога, здатність до покаяння, вміння не падати духом, шанобливе ставлення до старших, почуття відповідальності, почуття вдячності, безкорисливість, мудрість, поклоніння Богу. На наш погляд, окреслені у творах О. Духновича чесноти можна використовувати у шкільному вихованні для популяризації християнства й утвердження християнського способу життя.

Більш докладне студіювання різножанрової творчості мислителя, передусім буквара «Книжиця читалная для начинающихъ» (1848) [10; 11], молитовника «Хльбъ душ» (1851) [5], «Молитвенника для русскихъ дьтей» (1854) [12], «Литургического катихизиса» $(1851,1854)[4]$, програми для вихованців «Спілка св. Йоанна Хрестителя» [20], а також духовної поезії, байок, афроризмів дає змогу також збагнути та виокремити принципи і духовні цілі, які лежать в основі його духовної педагогіки:

1) Принцип любові. Любов - найголовніша засада виховання молоді. Цей принцип, без сумніву, спирається на зафріксовану в Новому Заповіті заповідь Любові, згідно з якою любов до Бога органічно поєднується 3 любов'ю до людини.

2) Христоцентричність, яка означає віру в Ісуса Христа як Спасителя людства і кожної людини, котрий своєю мученицькою смертю «смерть подолав і життя вічне нам дарував».

3) Виконання заповідей Христа і дотримання християнських релігійно-моральних приписів у повсякденному житті дитиною, юнаком, дівчиною, їхніми батьками.

4) Погляд на людину як на образ і подобу Божу.

5) Моральна відповідальність вихователя чи педагога перед Господом Богом за спрямування та межі виховного впливу.

6) Принцип ненасильства.

7) Принцип єдності педагогічних впливів із боку церкви, школи, родини.

8) Принцип особистісного підходу до виховання. Зокрема, він містить вимоги не придушувати особистість дитини, не стояти на ії̈ особистому шляху до Бога.

9) Антропологічний принцип, який ґрунтується на вимозі поважати, відчувати людину, знати, що відбувається в її душі.

10) Сумлінне вивчення духовної та культурної спадщини рідного краю. Національне виховання не тільки пов'язує особистість із рідним краєм, рідною країною, але й дає можливість усвідомити наднаціональну єдність людства перед Богом.

Висновки. Проведене дослідження показало, що непересічна постать Олександра Духновича одна з яскравих сторінок в історії розвитку української історико-педагогічної думки XIX ст., а його творчий доробок - вагомий внесок у систему тогочасних наукових пошуків, спрямованої на розвиток педагогічної науки, розроблення основ теорії та методики виховання. Педагогічна спадщина закарпатського вченого є синтезом, згустком найістотніших духовно-педагогічних здобутків українського народу й української народної педагогіки.

Доведено, що О. Духнович уперше у вітчизняній педагогіці на основі норм християнської моралі та моральних цінностей нашого народу і настанов народної педагогіки обґрунтував цілісну систему виховання та його зміст - комплекс ідей, думок, чинників, основних напрямів виховного впливу, визначив стрижневі принципи у концепції виховання - народність, природовідповідність і культуровідповідність.

Здійснений аналіз творчості О. Духновича дає змогу твердити, що в ній поєднується ґрунтовне знання як світської педагогічної науки, так і традиційного християнського виховання і вчення. Визначено ієрархію виховних цінностей мислителя і доведено, що сутнісною серцевиною педагогіки Олександра Духновича, стрижневим і домінантним напрямом усього процесу національного виховання згідно з його переконаннями є насамперед морально-релігійне і нерозривно пов'язане 3 ним патріотичне виховання. Як богослов, він теоретично обґрунтував мету, головні завдання, принципи, форми, засоби і методи морально-релігійного виховання і став основоположником християнського напряму у педагогічній думці Закарпаття. На основі вивчення різножанрової творчості мислителя можемо запропонувати тлумачення духовної педагогіки як теорії і практики виховання молоді, в основі якої - вчення Ісуса Христа, «христоцентричність», дух християнської любові, велич християнських істин та ідеалів.

Вивчення багатої творчої спадщини О. Духновича переконує в тому, що цілісний педагогічний процес в українській школі має будуватися на пріоритеті виховання, в основі якого - дух рідного народу. Сучасна українська школа повинна виховувати молодь у національно-релігійному дусі; домінантою має бути служіння Богові й Батьківщині, як учив ще в XIX ст. духовний наставник Олександр Духнович.

Перспективним напрямом подальших студій вважаємо створення узагальнюючої праці з історії виховних ідей на Закарпатті у XVIII-XX ст.

\section{БІБЛІОГРАФІЧНИЙ СПИСОК:}

1. Анєнкова І., Байдан М., Горчакова О., Руссол В. Педагогіка: модульний курс : навчальний посібник. Львів : Новий світ-2000, 2014. 567 с.

2. Ващенко Г. Виховний ідеал : підручник. Полтава : Полтавський вісник, 1994. 190 с.

3. Духнович А. Дьло от безділья Александра Духновича / ЛННБУ імені В. Стефраника. Відділ рукописів. (Копія) Ф. НТШ. Од. зб. 842. 1859. 347 с. 
4. Духнович А. Литургический катихизис, или изъяснение св. литургии и некоторых церковних обрядов. Будинъ, 1851. 207 с.

5. Духнович А. Хльбъ души или набожныя молитвы и пьсни для восточныя церкви православныхъ християнъ. Будинь, 1851. 184 с

6. Духнович О. Твори : в 4 т. Т. 2. / Вступ стаття «О.В. Духнович і його педагогічні погляди» С. 9-94. Ф. Науменка, М. Ричалки ; примітки, словник, покажчик І. Мацинського. Пряшів : СПВ - ВУЛ, 1967. 735 с.

7. Духновичь А. Народная педагогія въ пользу училищ и учителей селськихъ. Ч. 1. Педагогія общая. Львовъ : Типомъ Института Ставропигіянскаго, 1857. $91 \mathrm{c}$.

8. Духновичъ А. Справы народніи, 2/14 марта. Въстникъ... Вђденъ, 1850. № 15. С. 59.

9. Духновичъ А. Естественнодуховная разсужденія Александра Духновича Крылошанавъ Пряшовь / ЛННБУ імені В. Стесраника. Відділ рукописів. Ф. НД. № 174. 1855. 205 C.

10. Духновичъ А. Книжиця читалная для начинающихъ. Будинъ, 1847. 120 с.

11. Духновичъ А. Книжиця читалная для начинающихъ. Будинъ, 1850. Будинъ. 120 с.

12. Духновичъ А. Молитвенникъ для русскихъ дЂтей. Будинъ, 1854, 210 с.

13. Етимологічний словник української мови : в 7 т./ гол ред. О. Мельничук. Київ : Наукова думка, 1982. Т. 1. 632 c.

14. Зоря Галицкая яко альбумъ на годъ 1860. Львовъ : Типомъ Института Ставропигійского, 1860. $61 \mathrm{c}$.

15. Карпенчук С. Теорія і методика виховання : навчальний посібник. Київ : Вища школа, 2005. 343 с.

16. Маріянський Я. Суспільний характер релігії. Релігія в сучасному світі : матеріали до курсу релігієзнавства / за ред. Г. Зімоня ; пер. 3 пол. Г. Теодорович. Львів : Свічадо, 2007. С. 97-125.

17. Машталер О. Педагогічна і освітня діяльність О.В. Духновича / за ред. О. Мазуркевича. Київ : Вид-во «Радянська школа», 1966. 148 с.

18. Мосіяшенко В. Українська етнопедагогіка : навчальний посібник. Суми : ВТД «Університетська книга», 2016. 175 с.
19. Огієнко І. Українська церква. Нариси з історії Української православної церкви : у 2 т. Т. 1-2. Київ : Україна, 1993. 284 с.

20. Отчет двенадцатилетней деятельности 1862-1874 Общества «Св. Иоанна Крестителя и Предтечи в Пряшеве». Будапешт, 1875. 30 с.

21. Підласий І. Ідеали українського виховання. Рідна школа. 1999. № 12. С. 5-11.

22. Посльдняя моя пьснь. Галичанинъ. Львовъ : Типомъ Института Ставропигіанского, 1862. Кн. 1. Вып. 1. С. 19-20.

23. Ричалка М. О.В. Духнович педагог і освітній діяч. Братислава : Словацьке видавництво художньої літератури, 1959. 486 с.

24. Російщення України : науково-популярний збірник / за ред. Л. Полтави. Київ : Видання Українського Конгресового Комітету Америки, 1992. 408 с.

25. Рудловчак О. Біля джерел сучасності : розвідки, статті, нариси. Братислава, Пряшів : Словацьке педагогічне видавництво, Відділ української літератури, 1981. 416 с.

26. Словник біблійного богослов'я. Львів : Мicioнер, 1996. 936 c.

27. Сухомлинська О. Олександр Васильович Духнович. Українська педагогіка в персоналіях : у 2 кн. Кн. 1. X-XIX ст. / за ред. О. Сухомлинської. Київ : Либідь, 2005. С. 267-275.

28. Туряниця В. Духнович духу додає : навчальний посібник. Ужгород : УжНУ, 2006. 102 с.

29. Туряниця В. О.В. Духнович - педагог-новатор. Ужгород : УжНУ, 2003. 44 с.

30. Ушинський К. Твори : в 6 т. Київ: Рад. школа, 1954. T. 1. С. 51.

31. Федака Д. Олександр Духнович: сходинки у безсмертя. Ужгород : Видавництво TIMPANI, 2013. $132 \mathrm{c}$

32. Фізеші О.Й. Початкова школа Закарпаття в системних освітніх трансформаціях другої половини XIX - початку XXI ст. : дис. ... докт. пед. наук : 13.00.01 / Нац. пед. ун. імені М.П. Драгоманова. Київ : 2016. 587 c.

33. Ягупов В. Педагогіка : навчальний посібник. Київ : Либідь, 2002. 560 с. 